University of Nebraska - Lincoln DigitalCommons@University of Nebraska - Lincoln

1983

\title{
Monoculture, Polyculture, and Polyvariety in Tropical Forest Swidden Cultivation
}

Raymond B. Hames

Universit of Nebraska Lincoln, rhames2@unl.edu

Follow this and additional works at: https://digitalcommons.unl.edu/anthropologyfacpub

Part of the Social and Cultural Anthropology Commons

Hames, Raymond B., "Monoculture, Polyculture, and Polyvariety in Tropical Forest Swidden Cultivation" (1983). Anthropology Faculty Publications. 154.

https://digitalcommons.unl.edu/anthropologyfacpub/154

This Article is brought to you for free and open access by the Anthropology, Department of at DigitalCommons@University of Nebraska - Lincoln. It has been accepted for inclusion in Anthropology Faculty Publications by an authorized administrator of DigitalCommons@University of Nebraska Lincoln. 
Published in Human Ecology 11:1 (1983), pp 13-34.

Copyright (c) 1983 Plenum Publishing Corporation; published by Springer Verlag. Used by permission.

This article is based on a paper given at a symposium entitled "Does the Swidden Ape the Jungle?"

held at the December 1980 Annual Meeting of the American Anthropological Association in

Washington, D.C.

\title{
Monoculture, Polyculture, and Polyvariety in Tropical Forest Swidden Cultivation
}

\author{
Raymond Hames
}

Department of Anthropology, University of Nebraska-Lincoln, Lincoln, Nebraska 68588.

\begin{abstract}
A number of researchers have suggested that polyculture is characteristic of native tropical forest swiddens and have adduced theory from community ecology to account for its adaptiveness. Ye'kwana and Yąnomamö swidden cultivation is examined, and it is shown that polyculture is not practiced to any significant degree. Instead, the concept of polyvariety is introduced along with a number of other cultivation practices that more simply account for the adaptiveness of Ye'kwana and Yąnomamö gardening. In addition, comparative data from other parts of the tropical world indicate that polyculture is no more common than monoculture and recent advances in ecological research indicate that the diversity-stability hypothesis that underpins adaptive arguments of polyculture is in need of drastic revision.
\end{abstract}

Keywords: Swidden cultivation, Ye'kwana, Yąnomamö, neotropics, adaptation

\section{Introduction}

In the minds of many anthropologists, polyculture is to traditional swidden cultivation as monoculture is to modern industrialized agriculture. Polyculture refers to a type of planting arrangement whereby a variety of cultigens are systematically interplanted in a garden so 
as to mimic the structure and diversity of the natural ecosystem. Although the term polyculture seems to have been used first by Harris in his description of Yąnomamö Conklin (1969) and by Geertz (1970) and theoretically elaborated upon by Rappaport (1974). The distinction between monoculture and polyculture has found its way into a number of ecological texts (Janzen, 1975; Meggers, 1971) where it is argued that polyculture is an important adaptation in native swidden gardening in tropical forest environments.

In this article I have two interrelated aims. The first is to show that polyculture cannot be said to wholly characterize tropical subsistence swidden horticulture. Instead, the reliance on many varieties of a single cultigen species (polyvariety) appears to be common in native monoculture. The possible adaptive features of polyvariety are examined with data from the Ye'kwana and Yąnomamö Indians of Southern Venezuela. Second, the diversity-stability theory which underlies the polyculture argument has been found by ecologists to have little empirical validity; thus it is suggested that the use of the diversity-stability approach has drawn researchers away from using optimization approaches to understand the dynamics of swiddens.

\section{Development of the Concept of Polyculture}

Conklin's article "An ethnoecological approach to shifting cultivation" (1954) was written to overturn ten "problematic statements and assumptions" (p. 222) which he felt had surrounded discussion of the nature of shifting cultivation in the tropics. One of these problematic statements, sixth in Conklin's scheme, was that "swiddens are planted with a single predominant crop. Any swidden can thus be said to be a rice or a maize or a millet field or the like” (p. 223). Marshalling his own data, he argued that single-crop swiddens do not exist among the Hanunoo by noting that "up to forty crops have been observed growing in one Hanunoo swidden at the same time” (p. 228).

Later, drawing on Conklin's work, Geertz suggested that swiddens in low-density areas in Indonesia were not only polycultural but in addition were structurally similar to the natural forest ecosystem in the following three ways: (a) they exhibited a high species diversity, (b) nutrients were locked up in living forms, and (c) 
the swidden created a closed cover to protect this fragile soil (1970: 16). In Geertz's work we have perhaps the earliest statement of how swiddens are basically in tune with the natural ecosystem - largely through the extension of Conklin's observation that swiddens have a tremendous diversity of crops.

Finally, Rappaport's work on Tsembaga gardening (1974) gives the most sophisticated explanation of why swiddens mimic the structure and diversity of the natural ecosystem. Rappaport draws a parallel between complexity and adaptive stability of tropical forest ecosystems and swiddens, citing the work of community ecologists Odum (1971) and Margalef (1968). In comparing Tsembaga planting schemes to the distribution of plants in the surrounding forest, Rappaport remarks: "In the garden, as in the forest, species are not segregated by rows or section, but are intricately intermingled, so as they mature the garden becomes stratified" (1974: 375). Accordingly, the benefits for such a planting arrangement are (a) protection of the soil from the eroding, compacting, and leaching effects of rain, (b) high photosynthetic efficiency, (c) the prevention of species-specific pests and diseases, and (d) maximum use of surface and subsurface area. The combined effects of these benefits is a stable garden able to buffer environmental perturbations and degradation.

The work of Geertz, Conklin, and Rappaport on polycultural gardening practices in tropical forest swiddens brings up an important descriptive and theoretical problem. If the monocultural-polycultural continuum is to be an important variable determined by characteristics of an ecosystem, we must have an adequate means by which to measure it. Geertz implies that a species diversity index may be appropriate, but unfortunately none of the above-mentioned researchers has ever applied this measure to determine the degree of polyculture in a garden. Nevertheless, such a measure would be confounded by two characteristics of gardening: the existence of a number of different varieties of important staple species, and the relatively common practice of segregating species in patches within a garden. The theoretical issue revolves around the alleged relation between stability and ecosystem diversity. Recent community ecology theory and research indicates that minimally there is no relationship between complexity and stability and even that high species diversity and community complexity may be characteristic of immature ecosystems or unstable environments (Connell, 1978; May, 1973). 


\section{The Case for Polyculture Among the Yąnomamö}

Harris's article (1971) on swidden cultivation among the Yąnomamö (referred to as the Waica) is the most systematic statement we have on the nature of polyculture in an Amazonian society. (Meggers, 1971, generalizes about polyculture for Amazonia as a whole.) Harris describes Yąnomamö gardens as intricately stratified with the dominant plantains and bananas (both of which will be called plantains from here on since they are the same species; see Simmons, 1966) along with papaya forming a discontinuous canopy over cotton, manioc, and corn, and with sweet potatoes and yams carpeting and protecting the ground. A schematic profile, based on a photograph taken at the edge of a garden, shows this intricate arrangement. After contrasting Yąnomamö subsistence with up-river criollo market monoculture, he draws the following two generalizations: (a) polycultural gardens are cropped for longer periods of time and therefore are more stable than monocultural gardens; and (b) weed invasion may be the limiting factor on polycultural productivity, whereas soil nutrient depletion limits monocultural productivity. However, Lizot (1971) portrays an entirely different planting system for the Yąnomamö . In two different garden maps he shows that although the Yąnomamö plant a variety of crops in a single field, each species is segregated in separate patches; that is, a series of monocultural patches is laid out within a single garden.

I read both articles before entering the field. It intrigued me that Harris and Lizot had described two radically different planting practices in two villages quite near one another. Below, through a description of Ye'kwana and Yąnomamö planting schemes, I will argue that polyculture is not an accurate description of Yąnomamö or Ye'kwana gardening, that there is considerable temporal variability in garden planting, and, most importantly, that maintaining a stock of different varieties of the same crop species appears to be a major adaptive feature of their gardening. ${ }^{1}$

1 Data for these generalizations concerning garden composition and planting practices were gained through measurement and inventory of 23 Ye'kwana gardens in Toki and 7 Yąnomamö gardens in the allied village of Toropo-teri. Additional inspections, but not complete inventories, were made in gardens in the Yąnomamö villages of Shuimui-teri on the upper Orinoco and Haiyamo-teri, Namaho-teri, Sedukurauwa-teri, and Buhiimalawa-teri on the Padamo River and the Ye'kwana village of Kwashii'na on the Cuntinamo. See Hames (1980) for the location of the Padamo and Cuntinamo River villages. 
The number of crop species and varieties of species in Ye'kwana and Yąnomamö gardens varies from garden to garden, village to village, and region to region. Becher (1957) lists 38 species for Yąnomamö in Brazil, Lhermillier and Lhermillier (1964) list 30 for the area of the middle Maniviche, and Smole (1976) lists 35 for the Highland Parima area. I obtained 41 species for the Yąnomamö in the middle Padamo. The Ye'kwana, who share the Padamo with the Yąnomamö, have 71 (32 of which have magical uses), while those who live $100 \mathrm{~km}$ north in the Ventuari have 31 to 37, according to de Civireux (1973) and Fuchs (1964) respectively. The majority of cultigens are grown for food but a large number serve as condiments, manufacturing materials, medical and magical potions, cosmetics, fish poisons, and the like. (Many food and nonfood crops grown in kitchen gardens are not considered here.) For both the Ye'kwana and Yąnomamö , each of the major food crops has a number of varieties and there is a relationship between dependence on a species and the number of varieties of that species grown. ${ }^{2}$ For garden calories consumed by the Yąnomamö 1978), and from 9 to 15 varieties of this species are grown. Manioc and Xanthasoma sp. are second and third in importance, with up to six varieties of manioc and three of Xanthasoma sp. known. In addition, a number of lesser but still important secondary crops, such as corn, sweet potato, and yam, have two varieties each. For the Ye'kwana, manioc supplies approximately $65-75 \%$ of all garden calories; 15 varieties are grown. Plantains come in second at $10-15 \%$ of garden calories and the Ye'kwana cultivate from 5 to 8 varieties.

Given that the Ye'kwana and Yąnomamö cultivate from 31 to 71 species and 30 to 41 species, respectively, not to mention all the varieties of each species, some might consider this prima facie evidence for polycultural gardening. However, this is not the case because polyculture, as described by Rappaport and Harris, refers to the ways in which various species are distributed through interplanting. Multiple species is a necessary but not a sufficient condition for polyculture.

The term polyculture encompasses three different types of planting arrangement: (a) mixed cropping, or two or more crops grown simultaneously and intermingled with no row arrangement; (b)

2 Vickers notes (personal communication) that there is a positive relationship between dependence on a cultigen species and the number of varieties of that species for the SionaSecoya of Ecuador. 
interplanting, or long-term annual or biennial crops interplanted with short-term annual crops during early stages of plant development; and (c) interculture, or arable crops grown under perennial crops (all definitions after Kass, 1978: 4-5). Kass notes (1978: 5) that these definitions are not adhered to consistently by professional agronomists and argues that the term polyculture should be broadened to include any cropping arrangement where "two or more useful plants are grown simultaneously in the same area" (Ruthenberg, 1971, quoted in Kass, 1978: 5). Such an omnibus definition is overly vague (e.g., regarding what constitutes an "area") and masks the considerable diversity in planting practices from place to place which others (e.g., Geertz, 1970; Harris, 1971; Meggers, 1971; Rappaport, 1974) have sought to explain. Therefore, polyculture as used here refers to any planting arrangement which encompasses intercropping, mixed cropping, or interculture as defined above.

Since Yąnomamö and Ye'kwana planting arrangements essentially follow the same basic pattern, I will describe them together. Depending on the garden-maker's needs, manioc and/or plantains will cover $40 \%$ to $80 \%$ of the area of a new garden. For the most part, these staples usually occupy segregated or pure stands in the garden - that is, other crops are rarely interplanted among them. However, in new Yąnomamö gardens, but less so in Ye'kwana gardens, about half of the area devoted to plantains is interplanted systematically with Xanthasoma sp. and occasionally yams (Dioscorea trifidia). Occasionally, for the Ye'kwana, long and narrow segregated patches of corn are planted in the midst of manioc, but they are not interplanted. The balance of the subsidiary crops in Ye'kwana and Yąnomamö gardens occupy separate patches divided by species. What this pattern essentially amounts to, for the most part, is a series of species-specific patches within the bounds of a single clearing. One may speak of a plantain patch, or a manioc patch, or a peach palm patch, but rarely of a mixed or interplanted plantain-cotton-manioc patch as described by Harris.

The only portion of the garden which comes close to mimicking the structure and diversity of the rainforest, and hence is truly polycultural, is the plantain-Xanthasoma-Dioscorea zone. Aside from containing only two to three species, this association is short-lived. Xanthasoma and Dioscorea remain interplanted with plantains for only 2 to 4 months. They are harvested as soon as the plantains begin to shade 
them with their broad leaves. When these aroids are harvested they are replanted not among plantains but rather in small segregated plots. Therefore, at the end of the fourth month-in a garden having an average life span of 52 months - polyculture ceases and the entire garden is best characterized as a clearing that contains a series of monocultural patches. As $60 \%$ of the area of a typical Yąnomamö garden contains plantains, 35\% of which is intercropped for 4 months, and the average life span of a garden is 52 months, then polyculture can be said to typify Yąnomamö gardens about 3\% of the time. In addition, the number of species grown in a garden declines dramatically through time. ${ }^{3}$ Crops such as peach palm, plantains, and cotton, which seem to be able to withstand choking weeds and aggressive secondary saplings, are usually the only survivors in gardens after the fourth year.

Harris's incorrect attribution of polyculture to Yąnomamö gardens was caused perhaps by his short stay in the area and by his looking only at part of a newly planted field that was interplanted. It is noteworthy that the cultural geographer, Eden (who was a member of the Hovercraft expedition of which Harris was also part), in his study of native Piaroa and Guahibo gardening (groups to the north of the Yąnomamö along the Orinoco), writes that Harris "regards polycultural cropping as the traditional subsistence pattern and the tendency towards monocultural production, whether of manioc maize, or bananas, as a result of outside influences and cash cropping." But "the pattern described by Harris is not readily apparent in this area" (1974: 37). Eden goes on to describe both monoculture and polyculture for these native peoples, with monoculture as the slightly dominant pattern.

As mentioned previously, Lizot's published garden maps (1971), based on careful study over a considerable length of time, clearly contradict Harris. Smole's cultural geographic work on the Highland Parima Yąnomamö (1976: 144-146) shows, through a set of detailed garden maps with a time dimension, the following: (a) intercropped sections of the garden compose two-thirds to three-fourths of the total garden area; (b) certain crops such as manioc are monocultural; and, most importantly, (c) intercropped sections of the garden become monocultural within 2 to 4 months due to the harvesting of

3 Manner (1981) reports that cultigen diversity decreases with increasing garden age for Maring speakers in Highland Papua New Guinea. 
quick-maturing aroids that are not replanted. Obviously, his observations parallel my own for the Yąnomamö as well as for the Ye'kwana.

Harris (1971) also considers cash-cropping to be the cause of monoculture among the Ye'kwana. Although the Ye'kwana of Toki engage in limited cash-cropping, other Ye'kwana villages in the Padamo Basin monocultivate without cash-cropping. Frechione's recent work (1980) on cropping practices of the Ye'kwana of the Upper Ventuari directly refutes Harris on this issue by arguing that monoculture is indigenous to the area (see also Arvelo-Jimenez, 1971: 26, cited in Frechione, 1980: 8). Since only $18 \%$ of the manioc produced by the Ye'kwana of Toki (Hames, 1978: 265) is for the market one wonders why such a proportion would lead to the transformation of a supposedly native polycultural system to a monocultural system.

Given that I have established that polyculture is inconsequential among the Yąnomamö and Ye'kwana and that Eden (1974) has pointed this out for the native Guahibo and Piaroa of the same general region, one might ask what are the adaptive features of Yąnomamö and Ye'kwana crop mixes and planting and replanting schemes. By extension, it would be useful to know if other Amazonian peoples occupying similar habitats or native swidden horticulturalists in other parts of the tropical world also share these practices. But before this can be pursued, it would be helpful to examine briefly the theoretical underpinnings of the polyculture concept.

\section{The Adaptive Value of Garden Complexity}

Rappaport (1974) has made the most sophisticated explication of the adaptiveness of polyculture. His arguments are based on the work of the systems ecologists Odum (1971) and Margalef (1968). Odum and Margalef argue that adaptation and natural selection work at the level of the entire ecosystem. Following them, Rappaport notes that "in complex ecosystems successful species are not those that merely capture energy more efficiently but those that sustain the species supporting them" (1974: 377). The most fundamental fact to emerge in taking this perspective is that ecosystem structural complexity leads to longterm stability. This complexity, it is reasoned, allows an ecosystem to better buffer environmental stressors such as climatic change, disease, 
and the like. In linking interplanting as an analogue to ecosystem diversity, Rappaport concludes "the multiplicity of plants enhances the stability of the Tsembaga subsistence base exactly the same way that the complexity of the tropical forest ensures its stability" (1974: 378). Although Rappaport suggests (1974: 375) that interplanting is a means by which to maximize the yield of a garden, his major focus is on interplanting as an adaptation for avoiding environmental stress (pests, compaction, leaching, and erosion). Thus the emphasis is on stability and not on optimization.

While the diversity-stability hypothesis has gained some uncritical acceptance in cultural ecology (see Hardesty, 1977 for an exception), it has not fared so well in biological ecology. Goodman, in a review (1975) of the literature, points out that the complexity-stability hypothesis has not been demonstrated mathematically, empirically, or experimentally and concludes, "clearly, the belief that more diverse communities are more stable is without support. It is not so clear what sort of relation we should expect between diversity and stability" (1975: 260). Interestingly, he suggests that this hypothesis has its roots in the teleological assumptions concerning the wondrous balance of nature in 18th-century social science and philosophy. Later, this esthetically pleasing idea was presented as fact in textbooks and became a bulwark of conservationists' arguments (Goodman, 1975: 240).

One of the crucial problems with the diversity-stability hypothesis is lack of adequate definitions and measures of diversity and stability. Originally, MacArthur (1955) defined diversity as the number of interacting species in a system but measured it as the number of species and their abundances using the Shannon-Weaver information measure. Stability was defined by MacArthur (1955) as an inverse function of the probability of a system becoming extinct, but measured as the constancy of species populations in a system. Goodman (1975: 244), after reviewing attempts to refine the Shannon-Weaver diversity index, concluded that the measure is elusive and has no direct biological interpretation. Various other measures of stability have been employed ranging from constancy of numbers to persistence of communities. These are rather distinct concepts and their theoretical relationship to diversity is unclear (Hollings, 1973: 17-21).

With such ambiguous measures of diversity and stability, empirical tests of the diversity-stability hypothesis have met with little success. 
Comparative geographical approaches and perturbation analyses to test this relationship are methodologically faulty and thus do not provide critical evidence; when methodological problems are avoided, empirical tests "suggest that the diversity-stability hypothesis is a poor predictor of biological reality" (Goodman, 1975: 251). In addition, mathematical approaches to the problem (e.g., Levins, 1974; May, 1973) contradict the model, although Goodman (1975: 255, 257, 261) acknowledges that such

models are too abstract and simple to adequately mirror biological reality. The stability-diversity hypothesis is attractive to cultural ecologists working from a systems perspective. The key issue in systems analysis is the determination of homeostatic mechanisms that tend to keep a system stable or in dynamic equilibrium with the environment (Vayda, 1976; Vayda and Rappaport, 1976). Rappaport's definition of the key concept of adaptation clearly demonstrates this concern:

Any process, physiological, behavioral, cultural or genetic, which tends to keep the states of crucial variables ... within ranges of viability or tends to return them to such ranges should they depart from them may be taken, other things being equal, to be adaptive. (Rappaport, 1974: 384)

Obviously, any purported correlate of stability, such as diversity, would be important for such a concept of adaptation.

Modern evolutionary ecology defines an adaptation as any physiological process, or behavioral or morphological trait, that allows those individuals who have it to out-survive and out-reproduce those who do not have it. Rappaport's definition of adaptation emphasizes differential survival while ignoring differential reproduction or productivity. Although it is clear that survival is necessary for reproduction, individuals who have high rates of survival (i.e., longevity) may not be better adapted to the environment than those who have lower rates of survival but higher rates of reproduction. Therefore, survival or stability alone in the face of environmental stress cannot be equated with adaptation. Rappaport's functional approach emphasizing the survival value of traits is poorly equipped to deal with change.

Coupled to the adaptation-as-stability approach in cultural ecology is the belief that adaptation occurs at the level of the local group or population (Rappaport, 1968: 224) or of the entire ecological community (Odum, 1971; Rappaport, 1968: 224). This is known as group selection (Maynard Smith, 1964), and its proponents (Wynne-Edwards, 
1962) argue that individuals in highly social species depress their own chances of survival and reproduction to insure group or species survival. Group selection has been thoroughly discredited (Williams, 1966) as an evolutionary mechanism because the conditions under which it might occur are rarely met in nature (Lewontin, 1970). Refocusing on the individual as the locus of evolutionary change has led to the development of rigorous optimization models in evolutionary ecology (see Pyke et al., 1977, for a review) which are now increasingly employed by human ecologists (see the contributions in Winterhalder and Smith, 1981).

In summary, explanations of the adaptiveness of polycultural gardening have been based on theoretical constructs and relationships that have been shown to be inadequate by modern evolutionary ecological research. This is not to conclude that stability is not a goal in swidden cultivation, but rather to assess it from a more sophisticated theoretical perspective. The stability-diversity hypothesis has been useful for highlighting environmental problems with which swiddeners must deal, such as soil nutrient depletion, physical deterioration of the soil, erosion, pests and disease, and weeds. I will examine a number of cultivation practices in monocultural-polyvarietal Ye'kwana and Yąnomamö gardens as they relate to some of these environmental problems and the problem of optimizing garden yield relative to garden labor.

\section{Some Adaptive Features of Ye'kwana and Yąnomamö Gardening}

Compaction, leaching, erosion, weed competition, and pests are serious problems to which Amazonian gardeners must adapt their gardening practices. One may ask how this adaptation is accomplished in monocultural Ye'kwana and Yąnomamö gardens. An adaptive feature of these gardens stems from the fact that the dominant cultigens, manioc and plantains, seem able to shield the ground adequately from the adverse effects of harsh and frequent rain and the volitization of humus by the sun, a fact well understood by Amazonian ecologists (Goodland and Irwin, 1975; Meggers, 1971). Initially, manioc cuttings, which are planted in regularly spaced mounds of loosened soil, provide little protection for the soil. After about 2 or 3 months, when they are 
2-3 feet high and quite bushy, they begin to form a nearly impenetrable stand. Later in the season driving rainstorms topple many plants, forcing them to lie parallel to the ground while new shoots begin to grow perpendicularly. By the end of 6 months such a stand tends to look like a densely-woven mat over the ground, and probably lessens chemical and mechanical deterioration of the soil. Initially, plantains appear to provide little or no protection to the soil, even those portions of the garden which are interplanted with aroids. Only when plantains are well into the sixth month of growth do they begin to form an incomplete canopy over the soil. Since manioc and plantains are harvested and replanted or regenerated continually, only a small portion of the garden is subject to the stresses of sun and rain.

The productivity of plantains and manioc declines with garden age but the pattern of the two cultigens differs. The second harvest of manioc yields only from $45 \%$ to $55 \%$ of the first, while plantains show increases of $105 \%$ to $110 \%$ in the second and third harvests before dropping below the first-harvest level in the fourth harvest (Table I). A total of 33 soil samples was taken from various sites of primary forest, recently cleared, cultivated, and abandoned land, but damage during transshipment reduced the sample to 20, making generalizations concerning nutrient depletion and productivity tenuous. Nevertheless, according to Dale Baker (Agronomy Department, Pennsylvania State University), who supervised the soil analyses, the dramatic decline in manioc yields from first to second harvest may be attributable more to deterioration of the mechanical properties of easily in compacted soil, a fact recognized by the Ye'kwana in their explanation of why they prefer sandy soil for manioc (good drainage properties of sandy soil are also a factor according to the Ye'kwana). If soil compaction is indeed the major problem then my findings parallel the methodologically more sophisticated work of Scott on the Campa of Peru (1974: 61). It is apparent then that although dense monocultural manioc stands may protect the soil from mechanical deterioration for a short time, in the long run they do not.

The increase in yield for plantains occurs through a near-doubling of the number of plants in the garden after each harvest. As a plantain matures it produces from one to three ratoons (shoots). If not separated, the yield of a ratoon is slightly more than half of the parent plant. As a result, productivity of the garden remains the same 


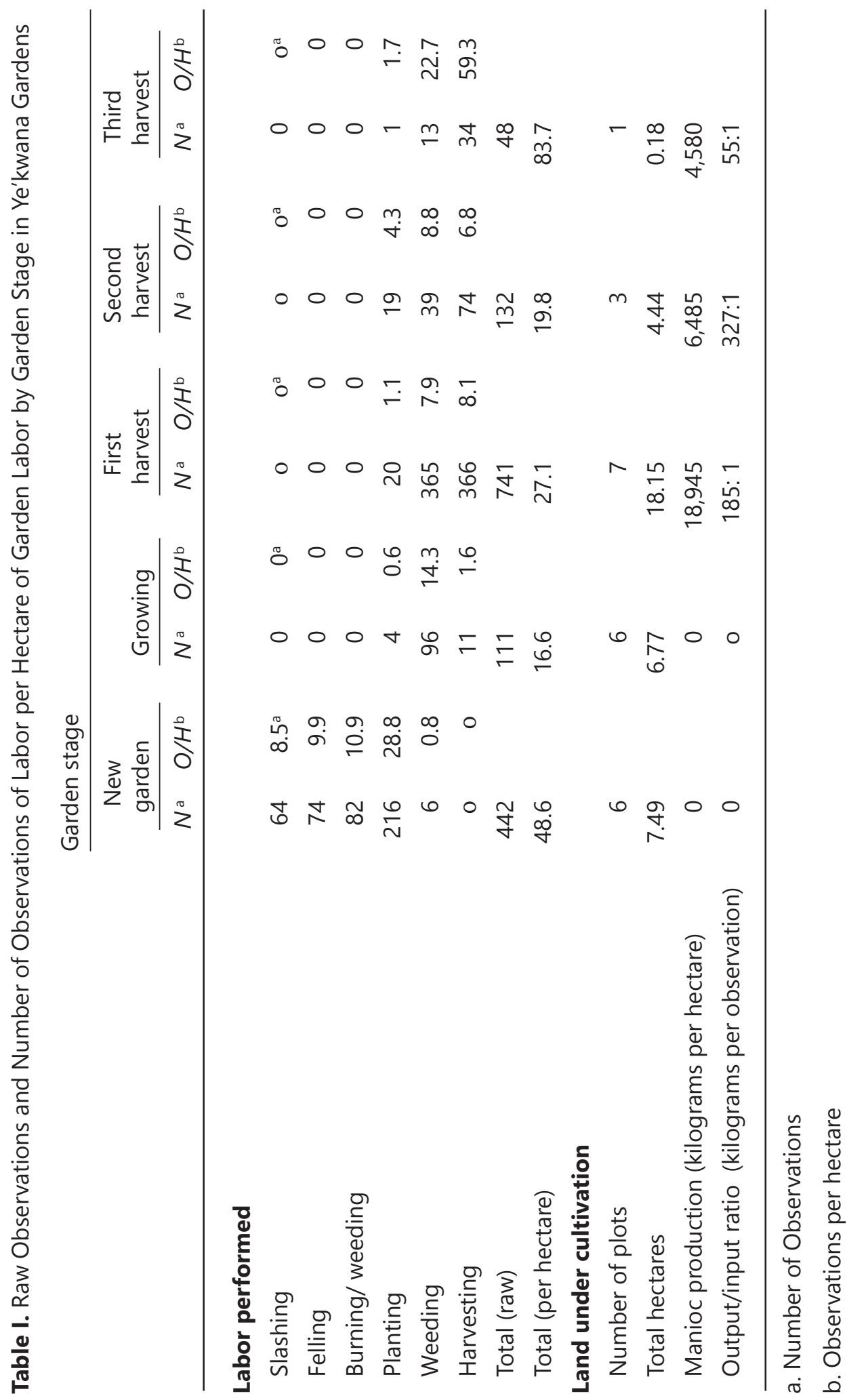


or increases slightly after the first harvest through the third harvest because the number of plants in a field increases through time. After manioc is harvested, the same number of stakes are replanted in, the same mound, which is slightly reloosened, but yields decline dramatically.

Weeds are the bane of existence for any swiddener, and whether weed invasion or soil depletion is the cause of garden abandonment is often debated (Nye and Greenland, 1965). Regardless of the underlying ecological causes, at the level of the individual gardener the relationship between garden productivity and the amount of labor which must be allocated for weeding is the immediate factor determining abandonment (Hames, 1978 and subsequent discussion; Smole, 1976). Ye'kwana and Yąnomamö abandon gardens; that is, they cease to weed or replant an area but continue to harvest it when the labor input can be decreased relative to productive output by clearing a new garden. At first dense manioc patches slow the growth of weeds, but eventually weeds win out. Plantain patches do not seem to shade the ground effectively against weeds at any time but they do seem to be able to tolerate them better than manioc. A plot cut from the primary forest that undergoes a good burn appears to be the best way to control weeds. Plots cut from secondary forest need to be weeded heavily within three weeks of a burn, whereas weeds are not a problem in gardens cut from primary forests for 6-9 months. Presumably, there are fewer weedy species in primary forests and because such forests tend to burn better, fire destroys their seeds and adventitious roots.

Data on garden productivity and labor investment that include information about clearing, burning, planting, weeding, and harvesting in relation to garden stage are seen in Table I. Data on labor investment were gained by a behavioral sampling method known as instantaneous scan sampling or spot checks (see Altmann, 1974 for a comparison of this method to other ethological methods, and Gross et al., 1979; Hames, 1979; Johnson, 1975; Werner et al., 1979, for ethnographic applications). Essentially, the method consists of sampling the behavior of all members of a population at random hours of the day and scoring each individual's behavior the moment encountered. From these data the amount of time allocated to various subsistence activities by each member of the population can be estimated reliably (Dunbar, 1975), as well as recording the location of the activity and other variables utilized in a coding scheme. The data in Table I include 
the raw number of observations for each garden activity by garden stage and the number of observations on a per-hectare basis for comparative purposes (i.e., observations divided by hectares).

As indicated in Table I, the total amount of labor and the different types of labor allocated per hectare of garden land vary considerably with garden stage. The stage "new garden" refers to gardens that were cleared while I was in the field, and "growing" gardens were those which had been cleared and planted approximately 4-6 months before my arrival. In growing gardens the harvesting of quick-maturing crops such as corn, taro, and sweet potato is complete and the first harvests of manioc and plantains are just beginning. "First harvest" gardens contain manioc and plantains 13-16 months of age that are being harvested almost daily with replanted or cloned manioc and plantains, composing ever-increasing portions of the garden through time. This mixture of mature, maturing, and newly replanted or cloned staples also composes second and third harvest gardens.

The amount of weeding in each garden stage follows no immediately discernible pattern. It is negligible in new gardens at $0.8 \%$ (observations per hectare) and then jumps to $14.3 \%$ in growing gardens and remains at high levels thereafter. A good burn in a newly cleared garden cut from primary forest apparently destroys the roots and seeds of weedy species, and gardens are nearly weed-free for about 5 months. The importance of selecting a new garden in primary forest can be seen in the "burn/weed" labor category. This labor category, like "slashing" and "feeling," occurs only in new gardens and documents the weeding done within 6 weeks after a garden is burned. Eighty-seven percent of labor observations for this category derives from two gardens that were the only ones to be cut from secondary forest (or land previously used for gardening) and indicates why both the Ye'kwana and Yąnomamö are loath to clear secondary forest for gardens. In one of the two cases weeds sprouting from adventitious roots were such a problem that the family who owned it was forced to build a shelter house in the garden and weed for about 2 continuous weeks before planting.

Although the weeding levels off to $7.9 \%$ and $8.8 \%$ in first and second harvest gardens respectively, this should not be read to indicate that weeds are less of a problem than in growing gardens. In reality, weeds are more numerous in first and second harvest gardens. Garden owners are losing the battle against them, and they are weeding just enough 
to ensure the likelihood of a decent second harvest. Finally, weeding reaches its highest level in third harvest gardens. Since there was only one third harvest garden being cultivated by the Ye'kwana, and it was small (o.18 ha) by their standards, the input and output figures may not be representative of third-year gardens. In this garden the weeding observations were abnormally high because it has not been actively maintained for several months. The even-higher harvesting figures were a result of dense weeds that had to be cut away prior to harvest and of weed roots binding with manioc, making extirpation laborious. ${ }^{4} \mathrm{Nev}-$ ertheless, according to Ye'kwana female informants third-year gardens are rarely maintained because they are so unrewarding.

The output/input ratios of garden labor to total harvest of manioc and plantains in each garden stage argues for the economic rationality of garden abandonment after the second harvest. The initial return on labor in gardening manioc for the Ye'kwana is $185 \mathrm{~kg}$ per observation, which increases to $327 \mathrm{~kg}$ per observation in second harvest gardens and then plummets to $55 \mathrm{~kg}$ per observation in third harvest gardens. Incomplete analysis of Yąnomamö plantain gardening suggests a similar but different pattern of garden abandonment. Yąnomamö gardeners usually maintain gardens through the third harvest, and the data indicate that the yield-per-observation ratio decreases drastically during the third harvest but that it is still higher than that which could be obtained by clearing a new garden. Although the Yąnomamö had no gardens being actively maintained for a fourth harvest, the direction of the data indicates that its output/input ratio would be inferior to that of a new garden. 5

4 Cultivation of this small garden through its third harvest was owed to the misjudgment of a family that was absent from the village during the communally organized clearing season. This family thought their existing younger gardens would be sufficient to supply them with staples, but they were wrong. I feel this to be a good example of how errors of judgment allow ethnographers to test the utility of alternative practices. Fuchs (1964), in his study of the Ye'kwana of the Upper Ventuari, suggests that manioc gardens give four harvests in the best of conditions and two in the worst of conditions.

5 1t should be noted that some of the variation in labor and yield for each garden stage could be the result of uncontrolled environmental variables. For example, although most gardens were made in a soil type the Ye'kwana name sadada hato (sandy soil), some were made in different soil types; felling a new garden adjacent to a recently abandoned garden makes weeds more of a problem compared to clearing a garden bounded by primary forest. Ideally, measures of inputs and outputs should have been made over a period of 4 or 5 years, controlling for soil type. 
Table II converts the raw observations in Table I to minutes per day per person for labor activities in gardens of various stages. It should be noted that the labor of females between the ages of 9 and 55 years and males between the ages of 14 and 60 are included in both tables (a sample of the activities of 46 individuals out of a total village population of 88). On a per-year basis this means that the Ye'kwana of Toki expended a total of $21,827 \mathrm{hr}$ on 37.03 ha of garden land, or 589 hr/ha/person.

Plant pests seem to present few problems for species of manioc and plantains. Monkeys, deer, and peccaries are prevented by intensive hunting from causing damage. Manioc is particularly susceptible to attacks of leaf cutter ants; the response to this problem, however, is not to interplant but to employ a variety of stratagems from direct attack with fire to a quick harvest and replanting elsewhere. Corn and tobacco can be devastated by a variety of insect pests. Swiddeners respond simply by monitoring these crops for signs of attack and removing pests by hand, when possible, or by making plans to harvest early, replant, or accept an inferior harvest. The rapid spread of devastating pests is reported in tropical commercial monocropping (Brookfield, 1959; Igbozurike, 1971a, 1971b), apparently because the host reservoir covers square kilometers in extent only in commercial situations. A few hectares of juxtaposed monocultural plots seem to lack the critical mass for such devastating attacks.

Table II. Minutes per Day of Garden Labor by Garden Stage in Ye'kwana Gardens

\begin{tabular}{lrrrrrr} 
& \multicolumn{2}{l}{ Garden stage } & & & \\
\cline { 2 - 7 } Labor performed & $\begin{array}{r}\text { New } \\
\text { garden }\end{array}$ & Growing & $\begin{array}{r}\text { First } \\
\text { harvest }\end{array}$ & $\begin{array}{r}\text { Second } \\
\text { harvest }\end{array}$ & $\begin{array}{r}\text { Third } \\
\text { harvest }\end{array}$ & Total \\
\hline Slashing & 3.3 & 0 & 0 & 0 & 0 & 3.3 \\
Felling & 3.9 & 0 & 0 & 0 & 0 & 3.9 \\
Burning/weeding & 4.3 & 0 & 0 & 0 & 0 & 4.3 \\
Planting & 11.4 & 0.2 & 1.0 & 1.0 & 0.1 & 12.7 \\
Weeding & 0 & 5.1 & 19.3 & 2.1 & 0.7 & 27.2 \\
Harvesting & 0 & 0.6 & 19.3 & 3.9 & 1.8 & 25.6 \\
Total & 22.9 & 5.9 & 39.6 & 7.0 & 2.6 & 78.0
\end{tabular}


Finally, the possibility of severe crop failure influences Ye'kwana and Yąnomamö gardening practices. Ye'kwana have been forced to abandon villages as a result of large-scale crop failure due to poor soil and flooding (Hames, 1978). For the Yąnomamö, Lizot reports (1974) on a recently contacted village which was subsisting largely on hunting and gathering because sufficient rains had failed to come after the planting of plantains. In order to respond to this potential problem the Ye'kwana overproduce by a factor of 30-40010 above basic subsistence needs (Hames, 1978).

The critical problems to which Ye'kwana and Yąnomamö gardeners must adapt are soil quality and drainage. They have responded by the development of many varieties of a single cultigen species. One may call this a polyvarietal strategy as opposed to a polycultural strategy. This idea is not new to students of shifting cultivation in the tropics. For example, such authorities as Freeman (1955) and Conklin (1954) have pointed out its importance, and Johnson (1972) and Knight (1973) comment on it in relation to crop experimentation. Brush (1977) argues for its adaptive significance among Andean potato cultivators in terms of a bank of genetic diversity. Essentially, Ye'kwana and Yąnomamö cultivators attempt to maintain the genetic diversity of staple food crops so they will be able to adapt to environmental variability.

Ye'kwana and Yąnomamö gardeners in the villages of Toki and Toropo-teri, respectively, cultivate 15 varieties of manioc and 8 of plantains. Each variety is distinguished in terms of productivity, taste, and cooking and processing qualities. But perhaps more importantly, how each variety performs in each soil and drainage condition is known and microenvironmental characteristics of gardens therefore determine which of the varieties will be planted. For example, manioc generally does best in well-drained loose and sandy soil. If the garden contains clay soils or is poorly drained, varieties that do better under these conditions will be planted. Usually, no more than 3 to 4 varieties will compose up to $90 \%$ of all manioc planted; the other 8 or 9 varieties will be planted in about $10 \%$ of the manioc portion of the garden, with some being planted in kitchen gardens. The Ye'kwana are fully conscious of why this genetic diversity is maintained: the garden cleared next year may require a different manioc variety complex than the one they are using currently. 
Selection of plantain varieties follows a similar pattern for the Yąnomamö The variety kuratha, while the second-highest yielding of the eight varieties used, is the most commonly planted. ${ }^{6}$ However, it is the hardiest in the face of environmental stress, particularly when rains fail to follow planting. In normal circumstances it is the most commonly planted variety but when conditions are particularly favorable a commercial variety dominates the garden.

The distribution of monocultural patches in a field is largely determined by drainage conditions. The most productive varieties of manioc do not tolerate poorly drained soils, in the driest parts of the garden, either in garden or near the apex of a convexly inclined other hand, are more subject to heat stress drained soils. Accordingly, they are planted gardens where the soil is most moist. The distribution not haphazard and they are planted in various believed that they will do best.

\section{Polyculture, Monoculture, and Polyvariety in Tropical Forest Swiddens}

Are the Ye'kwana and Yąnomamö, along with the Piaroa and Guahibo (Eden, 1974) of the Upper Orinoco, atypical in their predominantly monocultural planting practices? In Amazonia Meggers (1971) argues that polyculture is the dominant planting adaptation for terra firme populations. A search through the Amazonian literature is of little help because with few exceptions most discussions do not deal with planting practices or provide garden maps showing the distribution of crops in gardens. Exceptions are the works of van Hildebrand (1975) and Ruddle (1974), which contain detailed garden maps. Von Hildebrand's 19 garden maps of Vaupes cultivators indicate that nearly all gardens are strongly monocultural in composition and Ruddle's maps on the Yukpa show fairly extensive interplanting in new and growing gardens with increasing monoculture in older gardens (see also Wilbert and Ruddle, 1975). Most reports of manioc cropping (e.g., Carneiro, 1957) tend to indicate monoculture as the dominant pattern,

6 According to Smole (1976: 147-152), the cowata (kuratha, in my area) is the highest-yielding plantain variety except for the commercial banana. 
with some minor polyculture. However, recent research on Amazonian swiddens indicates that monoculture and polyculture vary between native societies. Beckerman (1983), writing on the Bari of northwestern Venezuela, Boster (1983) on the Aguaruna Jivaro of the Peruvian montana, and Thomas (1980) on the Pemon of the Gran Sabana of Venezuela all indicate that monoculture is the dominant planting practice; polyculture obtains for the Siona-Secoya of Ecuador (Vickers, 1983), the Cocamilla of Eastern Peru (Stocks, 1983), and the Achuara Jivaro (Ross, 1976: 184).

In Oceania, Barrau's early surveys of Melanesian (1958) and Polynesian (1961) gardening stresses the commonness of monoculture throughout the area. More recently, Brookfield (1974) has made a comparative survey of gardening in native Melanesia and New Guinea. In his analysis of cropping practices in 44 societies he found that $40 \%$ practiced intensive intercropping (polyculture) and $60 \%$ practiced slight to extreme crop segregation (monoculture). Interestingly, he found a fairly strong relationship between population density and degree of crop segregation, with densely settled populations tending to segregate crops and sparsely settled populations tending to intercrop. His finding are similar to those of Geertz for modern Indonesia (1970).

Miracle's survey (1967) on native swiddens in the Congo showed just the opposite of Brookfield's work in Melanesia. Intercropping was much more common than monocropping, especially among grain cultivators. This brief but broad-ranging survey of native tropical swidden horticulture seems to show clearly that polyculture cannot be said to totally characterize such systems. And it is evident, aside from Brookfield's population density hypothesis which does not apply in Amazonia, that we do not know why one or the other planting system is employed.

\section{Conclusion}

A number of investigators have suggested that polyculture is a widespread characteristic of native tropical forest swidden cultivators (Geertz, 1970; Igbozurike, 1971b; Kass, 1978; Meggers, 1971). Furthermore, some (e.g., Rappaport, 1974), using the diversity-stability hypothesis from community ecology, have made elaborate arguments 
to explain the adaptiveness of polyculture as opposed to monoculture. Comparative data supplied in this paper suggest that polyculture is no more widespread than monoculture in native tropical forest habitats and that recent theoretical advances in community ecology have cast considerable doubt on the diversity-stability hypothesis. More importantly, this paper discusses some of the significant adaptive dimensions of Ye'kwana and Yąnomamö cultivation practices such as polyvariety (maintenance of many varieties of staple species), overproduction, the use of garden microenvironments, and garden abandonment.

Swidden cultivation in tropical forest habitats, as elsewhere, has been a major adaptive human innovation. Studies continually reaffirm that it is the most efficient subsistence strategy for the production of food energy compared to the alternatives of hunting, gathering, and fishing. Although energetic efficiency is an important measure of adaptive success for any species (Smith, 1979), the reliability of a subsistence technique along with its ability to supply needed dietary protein, vitamins, and minerals which also limit humans must be evaluated in addition. The practices of polyculture, polyvariety, and overproduction appear to enhance gardening in a number of different ways. Overproduction of staple crops appears to be an adaptation against general and semicatastrophic environmental conditions (e.g., lack of rain) that diminish garden production severely. Interplanting (polyculture) may be an intensive way of maximizing the use of scarce garden land or land difficult to clear (e.g., in pre-steel-ax times) by covering every square meter of cleared land with crops. While interplanting may be land-efficient (by maximizing yield per area of land), it may decrease labor efficiency because of the difficulties of planting, weeding, harvesting, and monitoring an interplanted assemblage of crops. Monoculture (crop segregation) appears to be more labor efficient than interplanting and should be expected to occur when labor rather than land is in limited supply. Polyvariety is associated with monoculture, making it more adaptive when microenvironmental conditions vary widely, when the staple crop has a variety of uses (e.g., different varieties of manioc are used for the production of bread, farina, and starch), and when the environment is somewhat unpredictable. Finally, the production of a large variety of different staples, whether segregated or mixed, may be a way of meeting dietary needs 
which cannot be met by a single staple or through the alternative of hunting, gathering, and fishing (see Johnson, 1975; Johnson and Behrens, 1982; Kaplan, 1971).

The above hypotheses, as well as others pertaining to variation in swidden cultivation practices, should be tested because the diversitystability model is inadequate and cannot serve as a general model to account for monocultural and polycultural alternatives in tropical forest swidden cultivation.

Acknowledgments - I would like to thank my wife, Ilene Levin Hames, for helping me collect much of the data presented in this paper, especially data on garden size and composition. The data set would have been much smaller if it were not for her help and support in the field. I would also like to thank Ye'kwana and Yąnomamö women and men for identification of cultigen varieties and their characteristics, Dale Baker who supervised the soil analyses, and Tony Stocks for pointing out the importance of Koss' work. Research was made possible by a NIMH predoctoral fellowship (NIMH 5 Ro1 MH 26oo8-SSR; Napoleon Chagnon, Principal Investigator), and time to write it was made possible by a Summer Faculty Fellowship from the University of Nebraska.

\section{References}

Altmann. J. (1974). Observational study of behavior sampling methods. Behavior 48: $1-41$.

Arvelo-Jimenez (1971). Political relations in a tribal society: A study of the Ye'cuana Indians of Venezuela. Ph.D. Thesis, Cornell University. University Microfilms International: Ann Arbor, MI.

Barrau, J. (1958). Subsistence agriculture in Melanesia. Bernice P. Bishop Museum Bulletin 219, Honolulu.

Barrau, J. (1961). Subsistence agriculture in Polynesia and Micronesia. Bernice P. Bishop Museum Bulletin 223, Honolulu.

Becher, H. (1957). A importancia do banana entre os indios Suárá e Pakidai. Revista de A Antropológia 5: 192-194.

Beckerman, S. (1983). Bari swidden gardens: Crop segregation patterns. Human Ecology 11(1): 85-102.

Boster, J. (1983). A comparison of the diversity of Jivaroan gardens with that of the tropical forest. Human Ecology 11(1): 47-68.

Brookfield, H. (1959). Problems of monoculture and diversification in a sugar island. Economic Geography 35: 25-40.

Brookfield, H. (1974). Melanesian agriculture: Forty-four places compared. In Brookfield, H. (ed.), Melanesia: A Biogeographic Interpretation. Allen, London, pp. 95-124. 
Brush, S. (1977). Farming the edge of the Andes. Natural History 86(5): 32-41.

Carneiro, R. (1957). Subsistence in Social Structure: An Ecological Study of the Kuikuru Indians. PhD thesis, Anthropology Department, University of Michigan.

Conklin, H. (1969). An ethnoecological approach to shifting agriculture. In A. Vayda (ed.), Environment and Cultural Behavior. Natural History Press, New York, pp. 221-233.

Connell, J. (1978). Diversity in tropical rainforests and coral reefs. Science 199: 1302-1310.

de Civireux, M. (1973). Classificacion zoologica y botanica entre los Makiritare y los Karina. Antropológica 36: 3-82 .

Dunbar, R. I. M. (1975). Some aspects of research design and their implications in the observational study of behavior. Behavior LVIII (1-2): 78-98.

Eden, M. (1974). Ecological aspects of development among Piaroa and Guahibo Indians of the Upper Orinoco Basin. Antropológica 39: 25-65.

Freeman, J. D. (1955). Iban Agriculture: A Report of Shifting Agriculture of Hill Rice by the Iban of Sarawak. London: Her Majesty's Stationery Office.

Frechione, J. (1980). The gift of Kusui: The development of manioc dependence and monozoning in Ye'kwana agriculture. Paper presented at the 78th Annual Meeting of the American Anthropological Association, Cincinnati.

Fuchs, H. (1964). El sistema de cultivo de los Deukwhuana (Maguiritare) del alto rio ventuari, territorio federal amazonas Venezuela. America Indigena XXIV (2): 171-195.

Geertz, C. (1970). Agricultural Involution. University of California Press, Berkeley.

Goodland, R., and Irwin, H. (1975). Amazon Jungle: Green Hell to Red Desert. Elsevier, Amsterdam.

Goodman, M. (1975). Diversity-stability in ecology. Quarterly Review of Biology 50: 237-266.

Gross, D., Flowers, N., Ritter, M., Werner, D., and Eiten, G. (1979). Science 206: 1043-1050.

Hames, R. B. (1978). A Behavioral Account of the Division of Labor Among the Ye'kwana of Southern Venezuela. PhD Thesis, University of California, Santa Barbara.

Hames, R. B. (1979). A comparison of the efficiencies of the shotgun and the bow in neotropical forest hunting. Human Ecology 7(3): 219-252.

Hames, R. B. (1980). Game depletion and hunting zone rotation among the Ye'kwana and Yąnomamö of Amazonas, Venezuela. Working Papers on South American Indians 2, Hames, R. (ed.), Bennington College, Bennington, Vermont.

Hardesty, D. (1977). Ecological Anthropology. John Wiley, New York.

Harris, D. (1971). The ecology of swidden cultivation in the Upper Orinoco rainforest. Geographical Review 61: 475-495.

Hollings, C. (1973). Resilience and stability of ecological systems. Annual Review of Ecology and Systematics 4: 1-23.

Igbozurike, M. U. (1971a). Against monoculture. Professional Geographer 33(2): $113-117$.

Igbozurike, M. U. (1971b). Ecological balance in tropical agriculture. The Geographical Review 61: 519-529. 
Janzen, D. (1975). Ecology of plants in the tropics. Institute of Biology's Studies in Biology No. 58, Edward Arnold, London.

Johnson, A. 1973 Individuality and experimentation in traditional agriculture. $\mathrm{Hu}-$ man Ecology 1(2): 149-16o.

Johnson, A. (1975a). The energy costs of technology case. Proceedings of the 1975 Annual Spring Meeting of the American Ethnological Society.

Johnson, A. (1975b). Time allocation in a Machiguenga community. Ethnology 14(3): 301-310.

Johnson, A., and Behrens, C. (1982). Nutritional factors in Machiguenga food production decisions. Human Ecology 10: 167-189.

Kaplan, L. (1971). Archaeology and domestication in American Phaseolus (beans). In Struever, S. (ed.), Prehistoric Agriculture. The Natural History Press, New York, pp. 516-533.

Kass, D. (1978). Polyculture cropping systems: Review and analysis. Cornell International Agriculture Bulletin No. 32.

Knight, R. (1973). Institutionalized crop experimentation among shifting cultivators. Journal of Symbolic Anthropology 2: 1-18.

Levins, R. (1974). The qualitative analysis of partially specified systems. Annals of the New Academy of Sciences 53: 777-783.

Lewontin, R. (1970). The units of selection. Annual Review of Ecology and Systematics 1: 1-18.

Lhermillier, A., and Lhermillier, N. (1974). La Vie Economique et Sociale d'une Familiale Yanomami. Thesis, L'Ecole Pratique des Hautes Etudes, Paris.

Lizot, J. (1971). Société ou economie? Quelques themes a propos d'une communate d'Amerindiens. Journal de Société des Americanistes 6o: 136-175.

Lizot, J. (1974). El Rio de Los Periquitos: Breve relato de un viaje entre los Yanomami del rio Siapa. Antropológica 37: 3-23.

Lizot, J. (1978). Economie primitive et subsistance: Essai sur le travail et l'alimentation chez les Yanomami. Libre 4: 69-113, Payot, Paris.

MacArthur (1955). Fluctuation of Animal Populations and a Measure of Community Stability. Ecology 36: 533-536.

Manner, H. (1981). Ecological succession in new and old swiddens of montane Papua New Guinea. Human Ecology 9: 359-378.

Margalef, R. (1968). Perspectives in Ecological Theory. University of Chicago Press, Chicago.

May, R. (1973). Stability and Complexity in Model Ecosystems. Princeton University Press, Princeton, N. J.

Maynard Smith, J. (1964). Group selection and kin selection: A rejoinder. Nature 201: 1145-1147.

Meggers, B. (1971). Amazonia: Man and Culture in a Counterfeit Paradise. Aldine, Chicago.

Miracle, M. (1967). Agriculture in the Congo Basin. University of Wisconsin, Madison. Nye, P. H., and Greenland, D. J. (1965). The soil under shifting cultivation. Commonwealth Bureau of Soils Technical Communication No. 51, Farnham Royal, Bucks. Odum, E. P. (1971). Fundamentals of Ecology. Saunders, Philadelphia. 
Pyke, G., Pulliam, H., and Charnov, E. (1977). Optimal foraging: A selective review of theory and tests. Quarterly Review of Biology 52: 137-154.

Rappaport, R. (1968). Pigs for the Ancestors. Yale University Press, New Haven.

Rappaport, R. (1974). The flow of energy in an agricultural society. In Katz, S. (ed.), Biological Anthropology (Readings from Scientific American), W. H. Freeman, San Francisco, pp. 371-387.

Ross, E. (1976). The Achuara Jivaro: Cultural Adaptation in the Upper Amazon. PhD thesis, Columbia University.

Ruddle, K. (1974). The Yukpa cultivation system. Ibero-Americana No. 52, University of California Press, Berkeley and Los Angeles.

Ruthenberg, H. (1971). Farming Systems in the Tropics. Clarendon Press, London.

Scott, G. (1974). Effects of shifting cultivation in the Gran Pajonal, Eastern Peru. Association of American Geographers (Proceedings) 6: 58-61.

Simmons, N. (1966). Bananas. Longmans Group, London.

Smith, E. A. (1979). Human adaptation and energetic efficiency. Human Ecology 7(1): 53-74.

Smole, W. J. (1976). The Yanoama Indians: A Cultural Geography. University of Texas Press, Austin.

Stocks, A. (1983). Candoshi and Cocamilla swiddens in eastern Peru. Human Ecology 11(1): 69-84.

Thomas, D. (1980). Paper presented at the December 1980 Annual Meeting of the American Anthropological Association, Washington, D.C.

von Hildebrand, P. (1975). Observaciones preliminaries sobre la utilizacion de tierras y faunas por los indigenas del Rio Miriti-Paraná. Revista Colombiana de Antropologia 18: 183-291.

Vayda, A. (1976). Warfare in Ecological Perspective. Plenum Press, New York.

Vayda, A., and Rappaport, R. (1976). Ecology, cultural and noncultural. In Richerson, P., and McEvoy, J. (eds.), Human Ecology. Duxbury Press, North Scituate, Mass.

Vickers, W. T. Tropical forest mimicry in swiddens: A reassessment of Geertz's model with Amazonian data. Human Ecology 11(1): 35-46.

Werner, D., Flowers, N., Ritter, M., and Gross, D. (1979). Subsistence productivity and hunting effort in Native South America. Human Ecology 7(4): 303-315.

Wilbert, J., and Ruddle, K. (1975). Prehistoric cultural processes and cultivation change in a preliterate society. Antropos, 70: 272-289.

Williams, G. C. (1966). Adaptation and Natural Selection. Princeton University Press, Princeton.

Winterhalder, B., and Smith, E. (eds.) (1981). Hunter-Gatherer Foraging Strategies. University of Chicago Press, Chicago.

Wynne-Edwards, V. (1962). Animal Dispersion in Relation to Social Behavior. Hafner, New York. 